\title{
Emotional Intelligence in Distance Learning: A case study of English as a second language via distance learning
}

\author{
George Boon Sai Teoh, Agnes Wei Lin Liau \\ Universiti Sains Malaysia
}

\begin{abstract}
Correspondence concerning this article should be addressed to George Teoh, School of Distance Education, Universiti Sains Malaysia, 11800, Minden, Penang, Malaysia.E-mail: georgeteoh@usm.my
\end{abstract}

\begin{abstract}
Distance learners studying English confront emotionally demanding obstacles. A mixed methods study was conducted to explore the role that distance learners' emotional intelligence (EI) plays as they learn English. In phase one of the study, 238 students responded to a composite questionnaire that yielded their EI scores, demography, and viewpoints regarding the English course. In phase two, 18 volunteers selected based on their EI scores were interviewed to obtain qualitative data to build upon the quantitative results. This paper presents a case study of a student called Aini. The findings revealed that Aini's EI helped her manage her emotions, perceptions, and actions, and ultimately obtain her obligatory English credits for graduation. It is imperative to inculcate students' EI to help them manage their emotions in order to adapt and persevere, not only when learning English via distance learning but also to successfully accomplish one's goals in life.
\end{abstract}

Keywords: distance learning, emotional intelligence, case study, mixed methods study, situational barriers, institutional barriers, dispositional barriers

\section{Introduction}

Scholars acknowledge that learning a second language can be emotionally challenging (Hurd, 2000; Oxford 2015). Language learners have been found to experience anxiety, shame, anger, insecurity, sadness, confusion, contentment, pride, and joy (Oxford, 2015). In distance education, learning English as a foreign language (FSL) can become even more emotionally challenging due to the distance learning setting (Hurd, 2007; Oxford, 2015). Hurd (2000) explains that in traditional language classrooms, lessons and activities are planned and prioritised by the language teacher. The structure, support systems, regular checks, and better access to face-to-face communication with the teacher and course mates for seeking advice can help the language learner cope. However, for distance learners who are left to their own devices, it can become an emotionally exasperating experience (Hurd, 2000). Hurd (2007) highlights that the "inherently non-social nature of this mode of learning, which militates against the interdependence that many language experts would consider fundamental to successful language learning" (p. 242) would require the distance learners to manage their emotions in the absence of teachers and peers. If second language learners cannot concentrate well and have a weak learning ability, it could negatively affect their efforts to achieve academic accomplishments (Horowitz, Horowitz \& Koop, 1986, as cited in Homayouni et al., 2020) and induce negative emotions.

Emotions influence the manner in which people rationalise, decide, and act (Hewstone \& Stroebe, 2001; Lewis \& Haviland-Jones, 2000). Since emotional knowledge is vital for determining the decisions that one makes, the inability to regulate one's emotions can negatively affect one's efficiency when forming effective judgments. While examining poor judgement despite high intellect, Bechara et al. (2000) posited that "too little emotion has profoundly deleterious effects on decision making" (p. 193), which was as harmful as being too emotional. Hutchinson et al. (2018) advocate that with the advancements in understanding the role of emotions in neuropsychology, there should be more efforts taken to analyse the importance and functions of emotions. "It is now recognised that emotion and cognition processing are integrated in the brain and therefore jointly contribute to behaviour, particularly memory, attention and decision-making" (LeBlanc et al., 2015, as cited in Hutchinson, et al., 2018, p. 607). 
Recognising the impact of emotions, this study examines the role of Emotional Intelligence (EI) in the distance English language learning scenario. Oxford (2015) observed that "emotional intelligence is an important factor in language learning" (p. 61). This study is underpinned by the principles of EI, which initially were described as the capacity to control emotions, manage emotional situations effectively, and use emotional knowledge to make discerning decisions (Mayer \& Salovey, 1993). Later, Mayer and Salovey (1997), refined the definition of EI to the "ability to perceive accurately, appraise, and express emotion; the ability to access and/or generate feelings when they facilitate thought; the ability to understand emotion and emotional knowledge; and the ability to regulate emotions to promote emotional and intellectual growth" (p. 10). Research has also shown that EI can predict success in various aspects of life (Bar-On \& Parker, 2000; Goleman, 1995; MacCann et al., 2020; Salovey \& Mayer, 1990; Schutte et al., 1998).

In the field of education, numerous studies have been conducted to examine the influence of EI on the learning of the English language. Pishghadam (2009) investigated the role of EI in relation to the four language skills in second language learning. He compared the EI scores of 508 Iranian university students with their academic achievements in reading, listening, speaking, and writing skills. He concluded that second language learning was strongly associated with several dimensions of EI. Pishghadam found that stress management and being able to control one's emotions led to better reading skills, a high level of EI and intrapersonal abilities assisted in listening skills, interpersonal and intrapersonal competencies can contribute to better speaking skills, and good adaptability promoted better writing skills.

The findings concurred with Zarezadeh's (2013) study, which discovered that EI had a positive impact on English language learning amongst Iranian students. Intrapersonal intelligence, interpersonal intelligence, and general mood were found to influence speaking skills because the mutual performance characteristics needed for speaking count on these capabilities. Students' EI in terms of the ability to manage stress, maintain a good mood, and adapt to the context of a text helped them in reading. Next, students who have emotional awareness, self-esteem, and self-confidence proved to be better listeners.

Guven (2016) investigated the relationship between EI and university students' attitudes towards ICT and media tools for learning English. It was found that students who can understand their emotions and those of others are more likely to adopt ICT and media tools for learning English. Guven explained that learning a language is a social process that necessitates intrapersonal and interpersonal communication and collaborative interaction, which are aspects of EI that lead to the use of ICT for the enhancement of English language learning.

An experimental study involving EI intervention was conducted by Ebrahimi, et al (2018) to investigate the influence of EI enhancement on the speaking skills of EFL students. The learners in the treatment group who received EI enhancement achieved significant improvement in speaking. The speaking skills of the control group progressed but not as significantly as the treatment group's. The findings of the study supported the results of Soodmand Afshar and Rahimi's (2014) study that investigated the relationship among the EI, critical thinking, and speaking ability of Iranian students in English as a foreign language (EFL) classes. The participants completed an EI questionnaire, the California Critical Thinking Skills Test, and underwent an interview adapted from the IELTS Speaking Skill Test. The results indicated that high EI students had high speaking abilities. Conversely, low EI participants had low speaking abilities. The multiple regression analysis of the data showed that EI was the strongest predictor of the speaking ability of the participants rather than critical thinking. They concluded that "learners who are more able to control their own emotions and those of the others might be considered as better speakers than those who think critically" (p. 53).

In another study to investigate the relationship among EI, learning style, language learning strategy use, and the L2 achievement of Iranian EFL learners, Soodmand Afshar et al. (2016) found that strategy use and EI were strong predictors of second language achievement. Using Pearson correlation analyses, they discovered that second language achievement was significantly related to EI and language learning strategies used. But there was no significant relationship between learning styles and L2 achievement. The results of multiple regression analysis showed that strategy use, followed by emotional intelligence, was a stronger predictor of L2 achievement. They declared that 
high emotionally intelligent learners are able to guard against the interfering effects of negative emotions and neutralise their obtrusive influence, less emotionally intelligent learners are likely to succumb in the face of intricate and ill-defined situations and are unable to control destructive emotions (p. 647).

In a recent study, Aliasin and Abbasi (2020) investigated the relationship between EI and the use of metacognitive reading strategies by second language learners in Iran. Multiple regression analysis showed that "the EI scales of general mood and interpersonal skills significantly contributed to the prediction of the use of metacognitive reading strategies by EFL learners" (p. 31). They concluded that EI is positively connected to the students' emotional and cognitive capacity to deploy the respective metacognitive reading strategies to enhance their language learning.

In a Malaysian EI study, Hamdzah (2020) employed a cross-sectional survey design to examine the relationship between EI and Malaysian University English Test (MUET) performance among 250 undergraduate students at a technical university. The findings indicated that EI had a significant correlation with the students' MUET performance and can actually predict the students' MUET performance. The results of this study showed that EI influences student performance on English proficiency tests that evaluate listening, speaking, reading, and writing skills.

Finally, using structural equation modelling, Homayouni et al. (2020) investigated EI and English language anxiety amongst 321 bilingual students who were learning English. They defined language anxiety as "a feeling of tension, embarrassment, fear, apprehension, and worry about the negative evaluation of others that deprives the learner of the ability to take risks in various learning situations, including making contact and direct communication and face-to-face conversation (p.143). The results demonstrated that EI impacted English language learning both directly and indirectly via the English language anxiety experienced by the respondents in their study. Based on the findings, it was postulated that increasing EI can decrease language anxiety, resulting in enhanced English language learning (Homayouni et al., 2020). The findings of these studies confirmed the positive relationship between EI and English language learning.

A number of studies have investigated the impact of EI on distance and online learning. Among the studies, Valizadeh (2016) investigated the correlation between EI and EFL students' conceptions of autonomy in distance education. Learners' autonomy, defined as "the ability to manipulate one's own social surroundings and activities" (Valizadeh, 2016, p. 22), was found to be related to their EI. The results showed that the EI component of independence correlated significantly with learner autonomy. Autonomous distance learners' language learning experience is linked to their EI, whereby they demonstrate committed effort, action, and active involvement during distance learning. The students displayed a positive orientation towards learning EFL because they had positive attitudes in their learning experience.

In a similar vein, Zahed-Babelan and Moenikiab (2010) examined the role of EI in predicting students' academic achievement in a distance education system. The results of their study agreed with findings of previous studies indicating that EI predicted academic success in distance learning environments where there is a separation between teacher and student. Generally, distance learners need to depend on independent learning and intrapersonal capabilities to regulate themselves in the distance learning program. They asserted that "individuals must control negative emotions like fear, anxiety, and frustration so that positive emotions like enthusiasm and a sense of accomplishment can increase" (O'Regan, 2003, as cited in Zahed-Babelan \& Moenikiab, 2010, p. 1159).

In Pakistan, Buzdar et al. (2016) investigated the psychometric aspects, i.e., EI, of 432 English students as determinants of distance learners' foreign language readiness for online learning. Pearson correlation coefficients showed that the learners' readiness for and success with online learning was significantly and directly related to the distance learners' EI abilities such as self-emotions appraisal, others-emotions appraisal, use of emotions, and regulation of emotions.

In another study, Berenson et al. (2008) investigated the role of EI as a predictor for success in online learning environments. The participants consisted of Caucasian, African American, Hispanic, Asian, and Middle Eastern ethnic groups. They examined resilience, which is viewed as a dimension subsumed under the broader construct of EI as effective self-awareness. Resilience was defined as coping behaviours when students encounter 
obstacles, life stressors, and external obligations. The findings showed that resilience was strongly and directly associated with EI but did not predict GPA.They declared that successful students showed high resilience in "establishing and maintaining healthy relationships, ethical standards, the willingness to take risks for beliefs, the mastery of self in a social environment, and the persistence to work through difficult situations with selfconfidence" (Kemp, 2002, as cited in Berenson et al., 2008, p. 3).

Similarly, Engin (2017) conducted a correlational study to determine whether EI is linked to students' readiness in online learning. The findings indicated that students' EI was related to their online learning readiness. Students with high EI social skills, self-control, and well-being demonstrated higher online learning readiness behaviour. Moreover, the self-control dimension of EI predicted the students' readiness for online learning more than other dimensions of EI. Engin (2017) summarised that students with high EI social skills presented successful self-directed learning behaviour, such as "implementing own study plans, searching for support when learning problems are encountered, good time management, determining own learning targets, and having high expectations for learning" (p.38). These studies show that EI was found to positively influence students' readiness, autonomy, orientation, behaviour, and success in distance and open learning.

Overall, numerous studies have been conducted to investigate the influence of EI on academic achievement and English language learning in distance and online learning contexts. However, most of these EI studies (Aliasin \& Abbasi, 2020; Berenson et al., 2008; Buzdar et al., 2016; Engin, 2017; Hamdzah, 2020; Homayouni et al., 2020; Soodmand Afshar \& Rahimi, 2016; Zarezadeh, 2013) employed quantitative methods. The quantitative findings were informative, but the data were somewhat detached, reducing participants to mere numbers, which resulted in the loss of vital information about the participants' contexts and real-life experiences. These EI studies did not reveal rich qualitative data about distance EFL learners. Thus, this explanatory mixed methods case study sought to fill the gap by first collecting quantitative data and then collecting qualitative data to give a fuller picture of the phenomenon being studied. "The refinement results in exploring a few typical cases, probing a key result in more detail” (Creswell, 2012, p. 543).

This study explored the impact of distance learners' EI on their distance learning experiences at the School of Distance Education (SDE) Universiti Sains Malaysia (USM). SDE USM has been delivering distance education programmes in Malaysia since 1971. The SDE has transitioned from handing out lecturers' notes to students to the broadcasting of recorded lectures over the radio, to the sending of pre-recorded audio and video materials, to live audio and electronic board conferences as well as video conferencing, to e-learning portals, and finally to the present internet live video streaming (Hilmi \& Mustapha, 2017). Most of the time, distance learners study off campus except for the Intensive course, which is held every academic session. The Intensive course lasts for about two to three weeks. It is compulsory for all distance learners to attend on-campus activities at SDE USM during this time. All major, minor, and university courses have face-to-face sessions and other activities such as quizzes, tests, presentations, laboratory work, and tutorials during the Intensive course.

A study by Idrus (2007) discovered that the SDE students were mainly working adults from all over Malaysia who were offered an opportunity to pursue a tertiary education via a distance learning mode. Notably, Saw et al.'s (1999) study outlined that the adult students at SDE USM encountered various obstacles when they became distance learners because they had to grapple with many responsibilities. They needed to change from the traditional face-to-face-learning method they were accustomed to at school to a hybrid distance education programme that required more self-regulated learning. Another study by Azli et al. (2000) found that the female adult learners at SDE USM faced more challenging obstacles as they had to manage roles such as being spouses, mothers, and employees, which took up a lot of their time and reduced their social interactions. Through exploring the problems and coping mechanisms of distance learners, Dass's study (2001) documented that distance learners at SDE USM experienced emotional duress as they struggled with their academic challenges on top of their occupational, familial, and social obligations as adult distance learners. She highlighted that the 534 distance learners in her study faced problems with their English language courses. This was owing to the Malaysian public education system that utilises the Malay language as the medium of instruction.

Undisputedly, adult distance learners encounter a myriad of obstacles causing emotional trials that influence their engagement and accomplishments in learning (Cross, 1981; Hurd, 2000). They need to adapt to their new distance learning environment, which expects independent self-regulated learning and a familiarisation with 
new technologies for distance learning. Sugilar (2021) states that distance learners face numerous barriers to learning that are induced by inadequate support services, low student motivation, insufficient course information, and technical difficulties caused by online classes. The first category of barriers is referred to as Situational Barriers (SB). They comprise issues concerning learners' occupation, family, finances, environment, and insufficient social support. The second category is referred to as Institutional Barriers (IB). They comprise issues concerning the course programme and its implementation, academic workload, institutional support and facilities, assessment, as well as teaching and learning requirements. The third category is referred to as Dispositional Barriers (DB). They comprise issues concerning self-worth, low motivation and self-regulation, weak learning history, as well as individual inclinations and study patterns (Cross, 1981; Osam et al., 2016).

\section{Background of the Study}

The courses at SDE USM are mainly taught in the Malay language, except for the obligatory English credit units that the students must attain for graduation (SDE Guidebook, 2020/2021). Many students need to enrol for the English Level II and English Level III proficiency courses in order to graduate. These proficiency courses furnish the students with effective communication skills. Distance learners mainly self-study using modules, reference materials, recorded lectures, and attend some face-to-face lectures during the Intensive course. Assessments are conducted through coursework, continuous assessment, and the final examination.

In this scenario, learning English is difficult for the students as they are adults with differing learning styles and abilities to learn a second language. The opportunities for the students to communicate and learn English also differ as they come from different states in Malaysia. Some states are urban and use English more compared to other states that are more rural with less English usage in the community. Some SDE students have failed and had to repeat their English course(s). There were cases where the students passed their major and minor courses but were unable to graduate because they failed their English course(s). This was an emotionally distressing situation that made learning English an excruciating experience for distance learners.

This study addressed the following research question:

How does a distance learner's emotional intelligence influence her experiences in the English Level III course at the School of Distance Education, Universiti Sains Malaysia?

\section{Methodology}

\section{Data Collection}

An explanatory sequential mixed methods study (Creswell, 2012) was employed in this study. The rationale for this two-phase approach was to use the quantitative participant characteristics in phase one "to guide the purposeful sampling for a qualitative phase" (Creswell, Plano Clark et al., 2003, as cited in Creswell \& Plano Clark, 2006, p. 72) in phase two. This design allowed the researchers "to obtain quantitative results from a population in the first phase, and then refine or elaborate these findings through an in-depth qualitative exploration in the second phase" (Creswell, 2012, p. 543).

The students registered in the English Level III course were informed about the study after permission was granted by USM. They were duly informed about their rights, that participation was voluntary with no extra credits, and that the data would be anonymised to ensure confidentiality. In the briefing, they were urged to answer as honestly as possible. It was emphasized that their views about their learning experience would contribute to a better teaching and learning environment. All of the participants were debriefed to ensure that they were not negatively influenced by participating in the research.

\section{Participants}

In the first phase of the main study, a total of 238 distance learners returned the questionnaire that included their informed consent. The students took between 50 minutes and 65 minutes to complete the composite 
questionnaire. The participants consisted of 118 males and 120 females. Their ages ranged between 28 and 52 years old. Figure 1 shows the the EI scores of the participants.

\section{Assessments and Measures}

For the first phase of the study, the Schutte's Self-Report Inventory (SSRI; Schutte et al., 1998), a self-reported EI scale with 33 items that evaluates overall EI, was used to acquire the EI score of the participants. The lowest EI score was 33 and the highest EI score was 165. Schutte et al. (1998) reported that the SSRI includes three dimensions of EI, namely, "appraisal and expression of emotion in the self and others, regulation of emotion in the self and others and utilization of emotions in solving problems» (p. 175). The SSRI has good reliability, with .82 for internal consistency and .78 for test-retest reliability. It predicted the academic achievement of college students. The SSRI scale utilised to obtain the EI scores of the students has been found to generate reliable EI scores for adolescents and adults. In this study, the SSRI showed a Cronbach's alpha of .90, which indicated a high level of internal consistency (Pallant, 2011).

\section{Figure 1}

Distribution of the EI scores of the participants

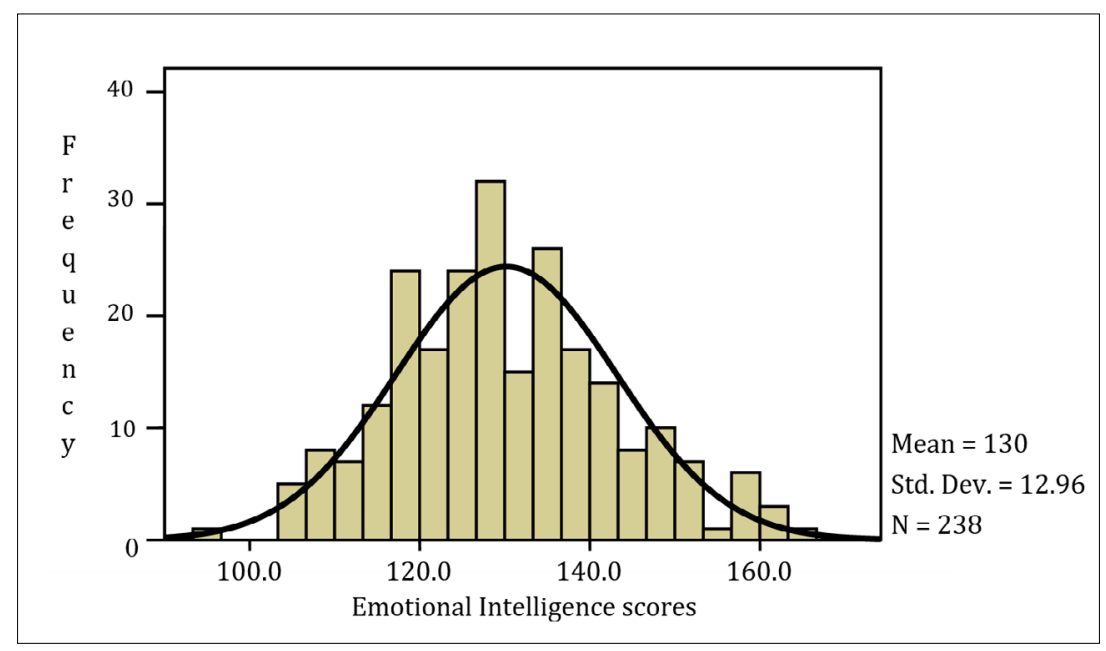

Most of the participants (66\%) scored close to the mean of 130 . The mode was 124 and the standard deviation was 12.96.Forty-three (18.1\%) of the respondents were in the High EI group with EI scores of 143 and above. One hundred fifty-seven (66\%) of the students were in the Mid EI group with EI scores between 143 and 117. Thirty-eight (15.9\%) of the students were in the Low EI group with EI scores of 117 and below.

In phase two, 18 students were chosen based on their EI scores, which were obtained from the first phase of the study to get "a sample that is satisfactory to their [the researchers'] specific needs" (Cohen et al., 2000, p. 103). The 18 students were selected to participate in the qualitative approach of the study as "qualitative data helps explain or build upon initial quantitative results" (Creswell, Plano Clark et al,. 2003, as cited in Creswell \& Plano Clark, 2006, p. 71). The 18 participants were individually interviewed using a semi-structured interview. This allowed for some flexibility in seeking clarification from the students about the issue of interest. The students could freely express their experiences based on their circumstances (Polit \& Beck, 2012) to disclose actual details, meanings, and connotations about the phenomenon being studied.

With assurance of confidentiality, the students allowed the interviews to be audio recorded. The students were made to feel comfortable and at ease. Each interview took between $60-80$ minutes.

This study showcases a distance learner pseudonymized as Aini. She was purposively sampled, indicating that she was chosen for specific purposes based on the researchers' "judgement of their typicality" (Cohen et al., 2000, p. 103) to obtain the data for the study. Cohen et al. (2000) contend that purposeful sampling is a nonprobability sample that "can prove perfectly adequate where researchers do not intend to generalise their 
findings beyond the sample in question" (p. 102). Aini was deemed to have potentially experienced emotional tribulations since her questionnaire showed that she previously failed English in the Malaysian Certificate of Education examination. She also failed English Level II of the distance education programme. After a re-sit, she obtained a C for the course. At the time of the study, it was Aini's second attempt at the Level III English course as she had failed it the previous year. Aini had an EI score of 138 (placing her in the Mid EI group) and was willing to participate in the interview. She was one of the few students who submitted comments via a diary that would allow for the triangulation of information regarding the phenomenon being studied. The interview included these questions:

1. What are your perceptions regarding the English Level III course?

2. Are there any obstacles that you faced in the English Level III course?

3. What did you do to manage your situation?

\section{Data Analysis}

The quantitative data gathered for this study from the survey questionnaire were analysed using SPSS Statistics for Windows (Version 26). The composite questionnaire also furnished the students' demography and perceptions about the English course. The audio-recordings of the interviews were transcribed and thematically analysed to discern, classify, and create themes that were significant for addressing the overarching research question of the study (Evans, 2018). The codes were obtained through the initial coding of significant words to the phenomenon of interest through close reading. It involved reading and rereading the interview transcripts until reaching a sufficient level of familiarity. These codes were further refined in an iterative manner. They were categorised into major themes that are significant to address the overarching research question of the study (Evans, 2018). The coding schemes included perceptions about the English course, the barriers experienced, and the actions taken to manage the situation. The consistency and reliability of the codes and themes were confirmed via inter-rater discussion and validation. Other than the main rater, there was a verifier rater. An inter-rater confusion matrix was drawn up based on the coding conducted by the main and verifier raters on $10 \%$ of the transcripts. The inter-rater reliability for the main rater and the verifier rater indicated a Cohen's kappa of 0.91. Cohen's kappa is a widely used measure of agreement. The value of $\kappa=0.91$ in the present study indicated that there was a very good agreement in coding (McHugh, 2012, p. 279). We strove to be transparent and reflexive in our construction and interpretation of the qualitative data to ensure the credibility of the results. The analysis of the qualitative data in the case-study also included the informants' direct quotes with their contextual background and the students' profiles and field notes that were individually recorded to provide rich detailed and circumstantial data about the informants (Bryman, 2004; Cohen et al., 2000; Evans, 2018).

\section{Results}

Aini was Malay and her mother tongue was the Malay language. She was 36 years old at the time of the interview. Aini came from a working-class family. Her father was a farmer and her mother was a homemaker. She joined the Social Science degree programme. She majored in Economics and minored in History. She had been in the programme for four years and this was her final year. She was married and had five children aged eleven years, ten years, nine years, eight years, and seven months. One of them was a special needs child with Down syndrome. She was a secondary school teacher. Her husband was with the regional Fire Department. They lived in the staff quarters of the regional Fire Department in a rural village in Kelantan. Incidentally, Kelantan is located on the East Coast of Peninsular Malaysia and USM is located on the West Coast of Peninsular Malaysia. The Malays in Kelantan are protective of their cultural identity; they speak the Kelantanese dialect more widely than the National Malay language and can be antagonistic towards a foreign language such as English. A journey by car from the SDE USM in Penang to Aini's home takes six to seven hours. Aini was verbal and expressive in conveying her thoughts and experiences as if she were sharing and unloading her emotional tension.

\section{Aini's Perceptions of the English Level III Course}

When asked about her perceptions regarding the English course, Aini said, "I am worried as I am in my fourth year. Passing the English courses is a requirement for graduation, but I failed it last year. I am more worried about my English grades than my other subjects." 
Reflecting on the English course, she added, "It is my greatest challenge. "She found the course challenging explaining that "the course is challenging as I can't write well in English. "She added, "I am very, very worried about the course because I don't understand the language." Being in her final year made the emotional challenge she felt more acute because if she did not pass it, she would not be able to graduate. She said, "I am afraid I cannot graduate due to failing the English course." Aini recorded the following comment in her diary: (I am very worried about my English course).

However, Aini viewed the course as advantageous. She said, "The course is useful as I can teach my children." She also viewed the modules favourably, stating, "The modules were beneficial, that is what I like about the course." On the one hand, it could be seen that Aini liked the course because the modules were beneficial. On the other hand, due to failing the course, Aini said, "I feel I have tried very hard, but I still failed. That is why I don't like the course."

At the same time, Aini viewed the course as disadvantageous. She mentioned, "It is a disadvantage because I need to re-sit it this year." Aini was also frustrated by paying more attention to her English paper but not passing the paper, at the cost of spending less time for her other courses that carried four units in comparison to the English paper that only carried two units. She added, "I pay more attention to my English course than my other courses which carry four units. It is not worthwhile."

Aini again stressed that the course was disadvantageous when she had to come to SDE USM during the long vacation intersession to re-sit the English Level III course that she failed. (The long vacation intersession was held to help final year students graduate by allowing them to re-sit the papers that they failed). Aini shared, "This course has been disadvantageous to me. I have had to come all the way here to re-sit the paper in order to graduate. It is such an inconvenience. I don't like it."

\section{Aini’s Perceived Situational Barriers}

Aini perceived her work as a great situational barrier. She commented, "I have many job responsibilities, teaching Living Skills and being in the Panitia [Committee]." She added, "I am also involved in academic and non-academic societies." She further explained, "I am also conducting workshops for the PMR exam students." She later remarked, "That was the first one, I will have to conduct at least three workshops this year." Aini's job exhausted her, she shared, "After work, sometimes I am too tired to study." This issue was also reported in Aini’s diary: (I am busy with many job responsibilities).

Aini also had great responsibilities in terms of her family and home. Aini said, "I am busy with my daily chores." She elaborated, "I have the internet at home, but I don't get a chance to use it because I'm busy and tired from caring for my children." Aini talked about her children, "I have five children to care for; eleven, ten, nine, and eight years old, and a seven-month-old baby."

Among her five children, Aini had one special child suffering from Down syndrome who needed more attention. She said, "Everyone is healthy except my special child who is suffering from Down syndrome who needs more attention, which is a challenge. However busy I am, I'll have to feed him otherwise he will not eat." Aini further explained, "I also had to give him more care as he could only walk at the age of three. He's better now as compared to when he was younger. Previously, he used to cry and turn blue because he had some problems with his heart, and I had to bring him to the hospital from time to time."

Aini further described how hectic her responsibilities were with the monitoring of her children's schoolwork and their welfare. Aini remarked, "My children are close to me and I have to help them with their schoolwork. If they cannot finish their work, they don't go to sleep. Sometimes they sleep at midnight." When Aini went to the mosque she had to bring her children along. She mentioned, "I bring the kids with me. When I return, I help them finish their work."

Upon reflection, Aini admitted that she did not have sufficient time for her English Language learning because of her numerous responsibilities at home and Aini's job takes up most of her time during the day. She reported, "I come home from school at 3:00 pm." Her job also required her to conduct a workshop that took up more of her time. She commented, "I conducted a workshop from 8-10 pm last night." Aini also shouldered many family 
and home responsibilities at the cost of her studies. She reasoned, "Because of my responsibilities, I can't find time for my studies."

Due to the lack of time, Aini's English studies lasted only two months. She explained, "It was only for two months, because I didn't have the time." She added, “It took me an hour to drive there and an hour to drive back, which was time consuming." Aini sometimes planned to read her books in school but she disclosed, "I sometimes bring my books to school hoping to do some studying but I seldom can find time to read them." Aini also mentioned that she sometimes spent time visiting her parents and her parents-in-law. She said, "We visit them regularly. Sometimes we have to spend three hours a week visiting them.”

Aini further disclosed some financial challenges. She said, "We sometimes have to send money to our parents, who are farmers." Aini also explained that during the Intensive course she had to spend some extra money to employ her former student as a babysitter for her new-born baby. She said, "I had to dig into my savings to pay the babysitter RM 300 for three weeks. Thank God this is my last year." Aini also had to pay tuition for her economics tutoring. She explained, "There is a teacher with a Master's in Economics at school. I asked him to help teach us. I paid him RM30.00 per hour, which was another financial strain.”

Distance was also a barrier for Aini. She was attending special classes that were about an hour's drive from her home after her busy day. "I went to special classes that were far away in Tanah Merah." Aini also mentioned some problems caused by other disruptions in her personal life. She suffered a miscarriage in the midst of her studies. She disclosed that it could have been due to attending her tuition classes that were far away from home after her busy day. "I had a miscarriage, which disrupted my studies."

Aini also tried to initiate a study group but unfortunately, it didn't last. She reported, "Early this year, a few of us formed a study group. But one by one we dropped out, so our plan was disrupted." She also recalled when her children were ill. She said, "My children haven't been sick for a long time, thank God. When they were sick my plans were disrupted."

According to Aini, her English language learning was not successful because of the English language practices in Kelantan. English was taught in Malay and the Kelantanese people spoke a variation of the standard Malay language that was different. In addition, there was no apparent motivation for the students to learn English effectively and competently. Aini recollected,

My teachers during my school days taught English in Malay all the way to my college days. That is the environment here in Kelantan. Most of us speak Kelantanese. In fact, where I teach now, the third week of school is English Week; but we still use the Malay language. There is no penalty for using the Malay language. That is why we remain weak in English.

Aini also experienced a lack of social support. Aini's husband worked with the District Fire Brigade on shifts. Aini divulged that he was helping her less nowadays. She said, "He was promoted to a senior officer position last year. A slight pay increase, but he now has more responsibilities and he helps me less." Aini did not have friends who could help her in English. She lamented, "I do not have friends who are good at English to help me." Aini also wrote about inadequate social support in her diary: (I can't find any friends who are good at English to help me).

\section{Aini’s Perceived Institutional Barriers}

Aini perceived her academic workload as an institutional barrier. She felt that her major and minor course combination was not a problem but her academic workload was heavy. She pointed out, "I am taking eight courses and the English course, 28 units altogether, which is heavy. I major in Economics and minor in History. The combination is alright. I like History so it does not cause much of a problem."

Aini remembered clearly that she had problems during the Intensive course. She had another baby before the Intensive course and had to bring the baby along as she was still nursing her. She employed a former student to take care of her baby when she attended lectures. However, she found the dormitory regulations that were not child friendly an institutional barrier. Aini recalled, 
I then had this new-born before the last Intensive course, and I had to bring her to the Intensive course because I was nursing her. She is fantastic, she didn't cause any trouble.She sleeps early at night, a very good baby. She stayed with me at the dormitory surreptitiously because the dormitory did not allow children.

Aini also mentioned that there was not enough teaching. She said, "Actually, the teleconferencing for the English course is insufficient." She complained about the English course teleconferencing schedule, "Also, the teleconference was held during unsuitable hours." Aini recalled scheduling problems during the Intensive course too, "Sometimes a few of my classes were scheduled one after another at night; ending late at night, like the English course." Aini complained, "Sometimes we had a terrible schedule. We had classes throughout the day, and we had to sit for assessments as well, so we had very little opportunity to revise."

Aini also mentioned some assessment issues as institutional barriers. She said, "During the last Intensive course, we only had one week to complete our English assignment." Aini felt it was difficult to complete the assignment in a week amidst her hectic schedule during the Intensive course. Aini also expressed that she found answering multiple-choice questions challenging saying that "the final exam had multiple-choice questions that were difficult."

\section{Aini’s Perceived Dispositional Barriers}

Aini's values and priorities created dispositional barriers. Being a devout Muslim, Aini illustrated this in her views. She stressed, "I personally teach my children the Quran. That is my duty." Aini's religious fervour was demonstrated in her statement, "At about $9.00 \mathrm{pm}$, I go to the mosque to attend religious talks to prepare for my afterlife." Aini's convictions based on her values and priorities overshadowed her studies.

Although Aini expressed interest in learning the English language, the circumstances and barriers she encountered greatly challenged her self-control. She said, "Yes, I am interested in studying English. Unfortunately, I gave up halfway." Aini herself acknowledged that her efforts to learn English were unsuccessful partly due to her lack of motivation. She said, "My motivation is not strong enough." Aini's low perception of herself as an English language learner formed a dispositional barrier that hampered the progress of her language learning. She disclosed, "I am not good at English. I didn't think I could do the assignments."

Aini's preference for studying English face to face with a lecturer was a dispositional barrier too. She explained, "I like to study with a lecturer in a face-to-face situation." Unfortunately, there was little opportunity for Aini to benefit from this mode of teaching in the SDE USM education programme because there were very few lectures in one academic year. However, Aini also admitted that during the lectures she was conscious about losing face in a huge crowd. Aini said, "I'm not afraid of the lecturers but I'm shy to ask questions as I don't want to appear silly."

\section{Aini’s Actions to Manage Her Situation}

Aini pointed out, "I enrolled for some English tutoring at the cost of RM300 per month." She also mentioned forming a study group, saying, "Early this year, a few of us formed a study group." Aini also tried multi-tasking to attend to her problem. She explained, "While I am teaching my children, I try to do some learning myself."

Knowing that she had limited time and many responsibilities, she organised the completion of her school duties before the Intensive course. She stated, "I would normally plan to finish my schoolwork before the Intensive course begins." Aini also made plan for doing her homework and studying. She stated, "I plan to go to the Regional Centre to do my revision in the morning just before my exams." Aini had also made contingency plans in case she failed. She said, "Anyway, this is my final year. If I fail, I will go to USM to re-sit the paper during the long vacation intersession."

During the Intensive course, Aini felt pressure when she received her English assignments. She admitted disengaging from the task for a short while. "I avoided it; I redirected my attention to other things for a day or two." She later recovered from the disengagement and completed her assignment. 
As a mother, Aini felt guilty for neglecting her special needs child when she focused on her studies. She commented, "Sometimes he goes to sleep without his food, and I feel guilty." Aini's perceptiveness of her son's needs, and her own emotions were vital for reminding her of her priorities in order to hold the family intact. To maintain harmony and bliss within the family, Aini also highlighted that "my husband is the head of the family, I try to be sensitive to his feelings.”

With regard to her failure in English, Aini disclosed, "I didn't feel too bad. I thought of my friends who were in the same boat as I am in and I accepted it." She also shared her feelings with her friends and sought their advice. Aini said, "I often seek the help and support of my friends to express my emotions and experiences." She added, "Sometimes I have fun with my children, and I become spirited again." There were other times when Aini indulged in going out as a family to promote emotional well-being. She said, "Occasionally we go out as a family to enjoy ourselves." Additionally, in her diary, Aini wrote, (I pray to God Almighty when I feel stressed). However, Aini admitted that sometimes she engaged in distressing emotions. She confessed, "When I feel bad and disturbed, I sometimes get depressed. I am not perfect."

\section{Discussion}

The purpose of the present study was to explore the influence of a distance learner's EI on her experiences with the English Level III course at the School of Distance Education, Universiti Sains Malaysia. The findings of the study are consistent with previous EI studies. Aini's perceptions, perceived barriers, and actions in her English learning experience appear to measure up with existing EI literature. Aini showed that she was able to perceive, appraise, and express her emotions about the English course quite readily. She liked the English course for the advantages that the course afforded her but there were moments and situations when she disliked the course due to her failure and the emotional challenges she encountered. However, due to her repeated failures, Aini was inclined to perceive the English course as emotionally challenging. Zarezadeh (2013) noted that some students "always appear to fail or reveal little progress despite all efforts and strivings they invest" (p. 1286). This is because learning a second language "gets severe for the adults because they are expected to communicate with a language which is different from their mother tongue" (p. 1286). Nevertheless, Zarezadeh (2013) found that EI had positively influenced English language learning amongst her Iranian participants. Homayouni et al. (2020) posited that language anxiety can be reduced by raising EI, resulting in improved English language learning.

Aini was able to recognise the numerous barriers she faced in learning English. She was aware that it was difficult for her, as she lived in a rural village in Kelantan where the community hardly used English, to learn a second language that is different from her mother tongue. Aini realised that she had to concentrate on her demanding job, her family, and especially her special needs child who needed constant care. Mindful that her time was limited, her tasks were numerous, and her schedule was packed, Aini did make some arrangements to succeed in her academic pursuits. Although, disruptions to her plans caused great emotional challenges and the impact was tremendous when her children fell ill, Aini regulated her emotions to deal with the challenges. These challenges corresponded with Cross's (1981) statements and Hurd's (2000) observation that distance learners of English endure isolation and insufficient time due to a variety of obligations that cause hardships. Aini's resilience is supported by evidence from Berenson et al.'s (2008) study that found resilience to be strongly associated with EI. Resilience was considered a dimension subsumed under the broader construct of EI as effective self-awareness. Aini's coping behaviours when she faced impediments, stressors, and external responsibilities can be attributed to her EI. This concurs with Valizadeh's (2016) study, which found that learners' autonomy was linked to their EI.

In recapitulating the significance of emotions in English language learning, Hurd (2007) emphasised that "emotions are interior signals and function as a guide for actions and cognition. They are therefore central to the way in which students approach what they are doing" (p. 253). In line with this, Aini demonstrated that she could perceive and understand her own emotions. She also considered the emotions of her husband and children. Being a Malay woman, whose husband does not possess a tertiary education, Aini endeavoured to be perceptive and understanding towards her husband's feelings to ensure a conducive environment for her to study. Taking advantage of her emotional knowledge, Aini took great care to recognise her husband's feelings and her children's needs, especially those of her special needs child with Down syndrome, to maintain harmony 
and bliss within the family. Norboevich (2020) postulates that "people with a high level of development of emotional intelligence have expressed abilities to understand their own emotions and the emotions of other people, they can control their emotional sphere, which determines their higher adaptability" (p. 103).

Relying on her EI, Aini exhibited the ability to access and/or generate feelings when they facilitated thoughts to enable her to manage the obstacles that she encountered in her English learning environment. She was cognizant of the barriers and recognised the reasons that jaded her emotionally. Aini accepted the onerous barriers that challenged her English learning and courageously managed her situation to obtain the minimum English language requirements for graduation. Aini displayed the ability to regulate her emotions to promote emotional and intellectual growth as well as positive outcomes. When Aini found out that she failed her English course, she initially felt sad. However, she later placated herself by comparing herself with her friends "who were in the same boat." Similarly, when Aini faced challenges, she utilised various strategies such as paying for English tutoring, forming a study group, and multi-tasking to attend to her problems. She organised her schedule and homework, and even made contingency plans in case she failed. This concurs with Soodmand Afshar et al.'s (2016) findings regarding the importance of strategy use and EI in EFL achievement. It was found that emotionally intelligent students can "guard against negative emotions and neutralise their obtrusive influence, less emotionally intelligent learners are likely to succumb in the face of intricate and ill-defined situations and are unable to control destructive emotions" (p. 647). Similarly, Aliasin and Abbasi (2020) found that students' emotional and cognitive capacity to use reading strategies to improve their language learning is positively related to their EI. Aini did not admit defeat amidst the barriers she faced. She attended to the problem and planned her activities to solve her problems rather than avoid them. Aini also engaged in activities to promote emotional well-being, such as finding respite from her stressful routine by playing with her children. Aini's ability to manage her emotional impediments shows that she was able to manage negative emotions like worry, anxiety, and exasperation and tried to promote positive emotions to be able to continue with her academic pursuits, as mentioned in Zahed-Babelan and Moenikiab's (2010) study. In a nutshell, EI is important because "it is not enough to be smart and hardworking - to have the added edge for success, students must also be able to understand and manage emotions to succeed at school” (MacCann et al., 2020, p. 174).

This case study can be considered a positive affirmation of the role of EI in a person's life experiences and success (Bar-On \& Parker, 2000; Goleman, 1995; Homayouni et al., 2020; MacCann et al., 2020; Salovey \& Mayer, 1990). Aini appeared to have operationalised her EI amidst the excruciating challenges she faced and was able to adapt and create a conducive environment for her learning, or more precisely, achieve the required English course credits for graduation. This phenomenon corresponds with the findings of Valizadeh's (2016) study on EI and learner autonomy. Aini can be described as an autonomous distance learner whose language learning experience is linked to her EI. She demonstrated committed effort, action, and active involvement in distance learning to achieve her goals. The manifestations of EI as shown in Aini's case demonstrate that EI is important for English language learners, especially those in distance learning, to make them adaptable and resilient when surmounting the emotionally challenging obstructions in their academic journey.

\section{Conclusion}

This study has shown that EI positively influenced a distance learner's experiences. Aini's EI helped her manage her emotions, perceptions, and actions to overcome her challenging situations to obtain her obligatory English credits for graduation. Distance learning programmes need to be continually improved to reduce the barriers faced by the students. All stakeholders in distance language learning must acknowledge the significance of emotions and EI in distance education. English language education providers must pay attention to the emotional needs of English language learners to ensure that the students are engaged, get support, and can achieve success in learning the target language. If the students do not get effective support, they may become disengaged, feel isolated, suffer negative learning experiences, and may even drop out of the programme. Language instructors need to be given EI training so that they become emotionally intelligent teachers.

Given the importance of EI, it is imperative to enhance students' EI via training, interventions, mentoring, and counselling programmes to endow them with the ability to withstand the difficulties and emotional tribulations in their arduous journey of learning English and in other forms of lifelong learning. EI enhancement could help 
individuals navigate, adapt, persevere, and thrive not only when learning English via distance learning but also but also for accomplishing one's goals in life successfully.

A limitation of this case study is that the results cannot be generalised to other students. Social desirability bias should be considered because the respondents' EI scores were obtained via a self-reported instrument. Researcher bias and the reactivity of the participants in this study cannot be totally ruled out. Future research can explore the impact of EI intervention on students' engagement and learning in the unprecedented remote teaching and learning scenarios brought on by the COVID-19 pandemic.

\section{Acknowledgements}

We would like to thank the anonymous reviewers, the editor, Elena V. Tikhonova, and Tim Thompson who greatly contributed to the improvement and publication of this manuscript. We also sincerely thank the generous distance learners for their contributions, SDE USM, and everyone who made this publication successful.

\section{Declaration of Competing Interest}

None declared.

\section{References}

Aliasin, S. H., \& Abbasi, S. (2020). The relationship between Iranian EFL learners' emotional intelligence and metacognitive reading strategies use. Journal of Language and Education, 6(2), 31-43. https://doi.org/10.17323/ jle.2020.9730

Arifin, M. H. (2018). The role of student support services in enhancing student persistence in the open university context: Lesson from Indonesia Open University.Turkish Online Journal of Distance Education, 3, 156-168. https://doi.org/10.17718/tojde.445116

Azli, N. A., Idrus, R. M., Atan, H., Jaafar, J., Abdul Rahman, Z., Abdul Latif, Z. (2000). The educational transition characteristics of female distance learners at Universiti Sains Malaysia. Malaysian Journal of Distance Education, 2(2), 47-54.

Bar-On, R., \& Parker, J. D. A. (2000). The handbook of emotional intelligence: Theory, development, assessment and application at home, school and in the workplace. Jossey-Bass.

Bechara, A., Tranel, D., \& Damasio, A. R. (2000). Poor judgement in spite of high intellect. In R. Bar-On, \& J. D. A. Parker (Eds.), The handbook of emotional intelligence: Theory, development, assessment, and application at home, school, and in the workplace (pp. 192-214). Josey-Bass.

Berenson, R., Boyles, G., \& Weaver, A. (2008). Emotional intelligence as a predictor for success in online learning. International Review of Research in Open and Distance Learning, 9(2), 1-16. https://doi.org/10.19173/irrodl. v9i2.385

Bryman, A. (2004). Social research methods (2 $2^{\text {nd }}$ ed.). Oxford University Press.

Buzdar, M. A., Ali, A., \& Tariq, R. U. H. (2016). Emotional intelligence as a determinant of readiness for online learning. International Review of Research in Open and Distributed Learning, 17(1), 148-158. https://doi. org/10.19173/irrodl.v17i1.2149

Cohen, L., Manion, L., \& Morrison, K. (2000). Research methods in education (5 $5^{\text {th }}$ ed.). Routledge/Falmer.

Creswell, J. W. (2012), Educational Research: Planning, conducting, and evaluating quantitative and qualitative research ( $4^{\text {th }}$ ed.). Pearson.

Creswell, J. W. \& Plano Clark, V. L. (2006). Designing and conducting mixed methods research. Sage.

Cross, K. P. (1981). Adults as learners. Josey-Bass.

Dass, L. (2001). Exploring problems and coping mechanisms of distance learners: A Universiti Sains Malaysia profile. Malaysian Journal of Distance Education, 3(1), 1-21.

Ebrahimi, M. R., Khoshsima, H., Behtash, E.Z., \& Heydarnejad, T. (2018). Emotional intelligence enhancement impacts on developing speaking skill among EFL learners: An empirical study. International Journal of Instruction, 11(4), 625-640. https://doi.org/10.12973/iji.2018.11439a 
Engin, M. (2017). Analysis of students' online learning readiness based on their emotional intelligence level. Universal Journal of Educational Research, 5(12). 32-40. https://doi.org/10.13189/ujer.2017.051306

Evans, C. (2018). Analysing semi-structured interviews using thematic analysis: Exploring voluntary civic participation among adults. In J. Lewis (Ed.), Sage research methods datasets. Part 1 (pp. 1-6). Sage. https:// doi.org/10.4135/9781526439284

Goleman, D. (1995). Emotional intelligence: Why it can matter more than IQ. Bloomsbury.

Guven,Z. (2016). The relationship between university students' attitudes towards ICT and media tools in learning English and their emotional intelligence. Selçuk İletişim, 9(3), 17-33. https://doi.org/10.18094/si.04069

Hamdzah, N. L. A, Subramaniam, I. D. \& Abidin N. Z. (2020). The relationship between Emotional Intelligence (EI) and the Malaysian University English Test (MUET) performance among technical students. International Journal of Learning, Teaching and Educational Research, 19(7), 280-297. https://doi.org/10.26803/ijlter.19.7.16

Homayouni, A.R., Abdollahi, M.H., Hashemi, S., Farzad, V., \& Dortaj, F. (2020). Social changes and need of learning English: Modelling of emotional intelligence and English language anxiety in bilingual's society. Journal of Sociological Studies of Youth, 11(39), 137-146. https://dx.doi.org/10.22034/ssyj.2020.679056

Hewstone, M., \& Stroebe, W. (2001). Introduction to social psychology: A European perspective ( $3^{\text {rd }}$ ed.). Blackwell.

Hilmi, M. F., \& Yanti Mustapha, Y. (2013). Eleven Years (1999-2009) of The Malaysian Journal of Distance Education: A Bibliometric Study. Malaysian Journal of Distance Education 15(1), 1-12.

Hurd, S. (2000). Distance language learners and learner support: Beliefs, difficulties and use of strategies. Links and Letters 7: Autonomy in Language Learning, 7, 61-80. https://ddd.uab.cat/pub/lal/11337397n7/11337397n7p61. pdf

Hurd, S. (2007). Distant voices: Learners' stories about the affective side of learning a language at a distance, Innovation in Language Learning and Teaching, 1(2), 242-259. http://dx.doi.org/10.2167/illt020.0

Hutchinson, M., Hurley, J., Kozlowski, D., \& Whitehair, L. (2018). The use of emotional intelligence capabilities in clinical reasoning and decision-making: A qualitative, exploratory study. Journal of Clinical Nursing, 27, e600-e610. https://doi.org/10.1111/jocn.14106

Idrus, R. M. (2007). Technogogy: A convergence of pedagogy, technology and content in distance education. Universiti Sains Malaysia.

Lewis, M., \& Haviland-Jones, J. M. (2000). Handbook of emotions ( $2^{\text {nd }}$ ed.). Guilford Press.

Mayer, J. D. (2001). A field guide to emotional intelligence. In J. Ciarrochi, J. P. Forgas, \& J. D. Mayer (Eds.), Emotional intelligence in everyday life: A scientific inquiry (pp. 3-24). Psychology Press.

Mayer, J. D., \& Salovey, P. (1993). The intelligence of emotional intelligence. Intelligence, 17(4), 433- 442. https:// doi.org/10.1016/0160-2896(93)90010-3

Mayer, J. D., \& Salovey, P. (1997). What is emotional intelligence? In P. Salovey, \& D. Sluyter (Eds.), Emotional development and emotional intelligence: Implications for educators (pp. 3-31). Basic Books.

Mayer, J. D., Salovey, P., \& Caruso, D. (2002). Mayer-Salovey-Caruso Emotional Intelligence Test (MSCEIT). MultiHealth Systems. https://doi.org/10.1037/t05047-000

MacCann, C., Jiang, Y., Brown, L. E. R., Bucich, M., Double, K. S., \& Minbashian, A. (2020). EI predicts academic performance: A meta-analysis. Psychological Bulletin, 146(2), 150-186. http://dx.doi.org/10.1037/bul0000219

McHugh, M. L. (2012). Interrater reliability: The kappa statistic. Biochemia Medica, 22(3), 276-282. https://doi. org/10.11613/bm.2012.031

Norboevich, T. B. (2020). Analysis of psychological theory of emotional intelligence. European Journal of Research and Reflection in Educational Sciences, 8(3), 99-104.

Osam, K. E., Bergman, M. \& Cumberland, D. M. (2016) An integrative literature review on the barriers impacting adult learners' return to college. Adult Learning, 28(2), 54 - 60.https://doi.org/10.1177\%2F1045159516658013

Oxford, R. L. (2015). Expanded perspectives on autonomous learners. Innovation in Language Learning and Teaching, 9(1) 58-71. https://doi.org/10.1080/17501229.2014.995765

Pallant, J. (2011). SPSS survival manual: A step by step guide to data analysis using the SPSS program ( $4^{\text {th }}$ ed.). Allen \& Unwin; McGraw Hill.

Pishghadam, R. (2009). A quantitative analysis of the relationship between emotional intelligence and foreign language learning Electronic Journal of Foreign Language Teaching, 6(1), 31-41. http://e-flt.nus.edu.sg/

Polit, D.F. \& Beck, C.T. (2012) Nursing research: Generating and assessing evidence for nursing practice ( $9^{\text {th }}$ ed.). Williams \& Wilkins. https://doi.org/10.1016/j.nepr.2013.04.001

Salovey, P., \& Mayer, J. D. (1990). Emotional intelligence. Imagination, Cognition and Personality, 9, 185-211. https://doi.org/10.2190/DUGG-P24E-52WK-6CDG

Saw, K. G., Awang, M. N., Idrus, M., Atan, R., Azli, H. A., \& Jaafar, N. (1999). Transitions in perceptions: Key elements in the facilitation of distance education. The Malaysian Journal of Distance Education, 1(1), 17-26. 
School of Distance Education Guidebook 2020/2021. (2020). School of Distance Education, Universiti Sains Malaysia.

Schutte, N. S., Malouff, J. M., Hall, L. E., Haggerty, D. J., Cooper, J. T., \& Golden, C. J., \& Dornheim, L. (1998). Development and validation of a measure of emotional intelligence. Personality and Individual Differences, 25, 167-177. https://doi.org/10.1016/s0191-8869(98)00001-4

Soodmand Afshar, H., \& Rahimi, M. (2014). The relationship among emotional intelligence, critical thinking, and speaking ability of Iranian EFL learners. Teaching English Language and Literature Society of Iran (TELL), 8(1), 31-59. https://doi.org/10.1016/j.tsc.2015.10.005

Soodmand Afshar, H., Tofighi, S. \& Hamazavi, R. (2016). Iranian EFL learners' emotional intelligence, learning styles, strategy use, and their L2 achievement. Issues in Educational Research, 26(4), 635-652. http://www.iier. org.au/iier26/soodmandafshar.pdf

Steinberg, P. F. (2015). Can we generalize from case studies? Global Environmental Politics, 15(3), 152-175. http:// doi:10.1162/GLEP_a_00316

Sugilar, S. (2021) Students' barriers to online learning. Turkish Online Journal of Distance Education, 22(1), $170-$ 178. https://doi.org/10.17718/tojde.849901

Tschannen-Moran, M., \& Carter, C.B. (2016). Cultivating the emotional intelligence of instructional coaches. International Journal of Mentoring and Coaching in Education, 5(4), 287-303. https://doi.org/10.1108/ IJMCE-02-2016-0008

Valizadeh, M. (2016). Iranian EFL students' emotional Intelligence and autonomy in distance education. English Language Teaching, 9(10), 22-30. https://doi.org/10.5539/elt.v9n10p22

Zahed-Babelan, A., \& Moenikiab, M. (2010). Examined the role of EI in predicting students' academic achievement in distance education system. Procedia Social and Behavioral Sciences, 2, 1158-1163. https:// doi:10.1016/j.sbspro.2010.03.165

Zarezadeh, T. (2013). The effect of emotional intelligence in English language learning. Procedia - Social and Behavioral Sciences, 84, 1286-1289. https://doi.org/10.1016/j.sbspro.2013.06.745 